\title{
Level Ekstrak Buah Nanas (Ananas Comosus L. Merr) dan Lama Perendaman Terhadap Kualitas Daging Itik Afkir
}

\section{Level of Pineapple Extract (Ananas comosus L. Merr) and Duration of Soaking The Quality of Afkir Duck Meat}

\author{
R. Novita*, Sadjadi, T. Karyono, dan R. Mulyono \\ Prodi Peternakan Fakultas Pertanian Universitas Musi Rawas \\ Jl. Sultan Mahmud Badarrudin II Kel. Air Kuti I, Lubuklinggau - 31628 \\ *E-mail: novitaririn91@yahoo.com
}

(Diterima: 14 Maret 2019; Disetujui: 02 Mei 2019)

\begin{abstract}
ABSTRAK
Penelitian ini bertujuan untuk mengetahui level ekstrak buah nanas (Ananas comosus L. Merr) dan lama perendaman terhadap kualitas daging itik afkir. Parameter yang diamati adalah pengaruh penambahan ekstrak buah nanas yang mengandung bromelin, lama perendaman dan interaksi antara kedua faktor terhadap susut masak, $\mathrm{pH}$, kadar protein, kadar lemak dan kadar air daging itik afkir. Itik yang digunakan adalah 18 ekor itik Tegal umur 84 minggu. Sampel yang digunakan untuk uji susut masak, pH, kadar air,kadar lemak, dan kadar air adalah daging paha. Rancangan penelitian menggunakan Rancangan Acak Lengkap (RAL) Pola Faktorial $3 \times 3$, dengan faktor pertama penambahan ekstrak buah nanas $(0 \%, 10 \%, 20 \%)$ dan faktor kedua lama perendaman $(15,30,45$ menit). Terdapat interaksi antara penambahan ekstrak buah nanas dan lama perendaman $(\mathrm{P}<0,01)$ pada kadar lemak dan $(\mathrm{P}<0,05)$ pada kadar protein. Penambahan ekstrak buah nanas dan lama perendaman dapat meningkatkan kadar protein daging itik afkir dan menurunkan kadar lemak daging itik afkir. Penambahan ekstrak buah nanas $10 \%$ dan waktu perendaman 30 menit menghasilkan kualitas daging itik yang terbaik karena mampu menurunkan kadar lemak dan meningkatkan kadar protein.
\end{abstract}

Kata kunci: ekstrak buah nanas, daging, itik afkir, kualitas fisik

\section{ABSTRACT}

The purpose of this study was to determine the level of pineapple extract (Ananas comosus L. Merr) and the duration of the quality of rejected duck meat.parameters that discuss the contribution of pineapple fruit extract containing bromelin, soaking time and interaction between the two factors on cooking shrinkage, $p H$, protein content, fat content and reject water content of duck meat. The duck used was 18 Tegal ducks aged 84 weeks. The sample used for the test for cooking shrinkage, pH, water content, fat content, and moisture content is thigh meat. The study design used a Completely Randomized Design (CRD) Factorial Pattern $3 \times 3$, with the first factor adding pineapple extract $(0 \%, 10 \%, 20 \%)$ and the second factor was immersion time $(15,30,45$ minutes). There is an interaction between the addition of pineapple fruit extract and soaking time $(P<0.01)$ on fat content and $(P<0.05)$ on protein content. The addition of pineapple extract and soaking time can increase the rejected protein content of duck meat and reduce the fat content of rejected duck meat. The addition of $10 \%$ pineapple extract and 30 minutes soaking time produced the best quality duck meat because it can reduce fat levels and increase protein levels.

KKeywords: meat, physical quality, pineapple fruit extract, unproductive ducks 


\section{PENDAHULUAN}

Pentingnya kebutuhan gizi khususnya protein hewani serta kesadaran masyarakat akan gizi yang baik terus meningkat setiap tahunnya sebanding dengan peningkatan jumlah penduduk. Kebutuhan gizi tersebut khususnya protein hewani dapat diperolehdengan mengkonsumsi produkproduk peternakan. Ternak unggas adalah salah satu hewan ternak yang dapat dimanfaatkan sebagai sumber protein hewani. Itik merupakan salah satu ternak unggas yang cukup mempunyai potensi besar untuk dikembangkan sebagai penghasil daging dan sudah cukup terkenal di masyarakat selain ayam (Illanes, 2008).

Itik afkir adalah itik petelur dan atau itik pedaging yang produksinya telah menurun dengan kisaran umur 3-3,5 tahun (Latifa, 2007). Periode pertumbuhan pada itik dibagi menjadi berapa periode yaitu periode layer adalah itik berumur 6 bulan hingga masa afkir (3 tahun). Menurut Chang et al. (2013) menyatakan bahwa kealotan daging itik afkir dikarenakan jaringan ikat (kolagen) lebih banyak dibandingkan dengan itik muda, hal ini dipengaruhi oleh komposisi asam amino kolagen dan sifat kimiawi yang berperan penting dalam tingkat kekenyalan daging.

Keunggulan dari daging itik afkir adalah kandungan proteinnya yang tinggi namun mempunyai kelemahan aroma yang amis, kalori yang rendah, kadar lemak tinggi dan ikatan kolagen yang banyak sehingga mempengaruhi keempukan daging. Oteku et al. (2006) menyatakan bahwa daging itik afkir bertekstur liat, kadar lemak tinggi, kadar asam lemak tak jenuh $60 \%$ serta memerlukan proses pengelolahannya agar tidak berbau amis yang disebabkan oleh komposisi asam lemak, proksidan dan oksigen sehingga berpengaruh terhadap aroma daging. Hal ini menyebabkan nilai jual ternak itik sebagai sumber daging dan itik afkir sangat rendah. Konsumen menghendaki daging yang mempunyai mutu yang baik, terutama dalam hal keempukan, cita rasa, dan warna. Menurut
Lawrie (2003) keempukan daging dipengaruhi oleh protein jaringan ikat, semakin tua ternak jumlah jaringan ikat lebih banyak, sehingga meningkatkan kealotan daging.

Tanaman nanas yang memiliki nilai ekonomis adalah buahnya. Didalam buah nanas mengandung enzim protease (proteolitik) yang disebut enzim bromelin. Ekstraksi buah nanas menghasilkan bromelin yang berfungsi dapat mengempukkan daging. Enzim bromelin didapat dari E.C yaitu E.C 3.4.22.33 yang merupakan enzim golongan ketiga. Ikatan peptide yang dihidrolisis pada subkelas 22 yang meerupakan gugus aktif dalam enzim dan menghasilkan enzim bromelin (Basri, 2014).

Salah satu cara mengempukkan daging adalah dengan perendaman daging dengan enzim proteolitik (protease). Proses pengempukan terjadi karena proteolisis pada berbagai fraksi protein daging oleh enzim. Proteolisis kolagen mengakibatkan shear force kolagen berkurang, sehingga keempukan daging meningkat. Proteolisis myofibril menghasilkan fragmen protein dengan rantai peptide lebih pendek. Semakin banyak terjadi proteolisis pada miofibril, maka semakin banyak protein terlarut (Srigandono, 2011).

Lawrie (2003) menyatakan pada proses mengempukkan daging dapat dilakukan dengan merendam daging itik didalam enzim proteolitik seperti bromelin. Pada proses perendaman daging tersebut terjadi proses hidrolisis serat otot pada protein daging serta larutnya nuklues dari serat otot dan jaringan ikat dan terdegradasinya serat otot yang akan meningkatkan keempukan daging. Selanjutnya Winarno (2009) menyatakan bahwa didalam buah nanas terdapat enzim bromelin berupa enzim protease yang mampu menghidrolisis protein daging.

Permasalahan tentang nilai keempukan daging khususnya daging itik afkir dapat diatasi melalui cara perendaman dalam ekstrak buah nanas sebagai bahan pengempuk daging. Dengan metode ini diharapkan akan meningkatkan nilai keempukan daging 
disamping upaya untuk pengelolahan pangan asal ternak khususnya daging itik afkir. Hasil penelitian Dhiah et al. (2011) menyatakan bahwa Penambahan ekstrak buah nanas $15 \%$ dan waktu pemasakan 60 menit menghasilkan kualitas daging itik yang terbaik.

Berdasarkan uraian diatas maka perlu dilakukan penelitian level ekstrak buah nanas (Ananas comosus l. merr) dan lama perendaman terhadap kualitas daging itik afkir.

\section{METODE}

\section{Tempat dan Waktu}

Penelitian ini telah dilaksanakan di Laboratorium Fakultas Pertanian Universitas Musi Rawas dan dilanjutkan di Laboratorium Institut Pertanian Bogor dari bulan Januari sampai Maret 2018 untuk uji Kadar Air, Kadar Protein, dan Kadar Lemak.

\section{Bahan dan Alat}

Bahan yang digunakan yaitu itik Tegal afkir umur 84 minggu (18 ekor), baskom, buah nanas masak, aquades, kertas saring, dan kertas label, sedangkan alat yang digunakan yaitu pisau, timbangan analitik, batang pengaduk, blender, $\mathrm{pH}$ digital, kompor, dan panci.

\section{Rancangan Percobaan}

Metode penelitian yang digunakan adalah metode eksperimental dengan menggunakan Rancangan Acak Lengkap (RAL) faktorial terdiri dari faktor A dan faktor B menggunakan 3 taraf perlakuan dengan 3 kali ulangan sehingga diperoleh 27 unit percobaan, setiap unit percobaan (tiap unit) di ulang 3 kali. Adapun taraf perlakuan yang akan di ujicobakan sebagai berikut :

Faktor A (Level Ekstrak Buah Nanas)

$$
\begin{aligned}
\text { A0 } & =0 \mathrm{ml} \text { Ekstrak Buah Nanas } \\
\text { A1 } & =10 \mathrm{ml} \text { Ekstrak Buah Nanas } \\
\text { A2 } & =20 \mathrm{ml} \text { Ekstrak Buah Nanas } \\
\text { Faktor B (Lama Perendaman) } & \\
\text { B0 } & =15 \text { Menit }
\end{aligned}
$$

$$
\begin{aligned}
& \mathrm{B} 1=30 \text { Menit } \\
& \mathrm{B} 2=45 \text { Menit }
\end{aligned}
$$

\section{Cara Kerja}

\section{Preparasi Daging Itik}

Daging itik bagian paha dipisahkan dari kulit dan tulang. Daging paha digunakan untuk uji kadar protein, uji kadar lemak, uji kadar air, uji pH, dan susut masak.

\section{Preparasi Ekstrak Buah Nanas}

Langkah pembuatan ekstrak nanas melalui beberapa proses, yaitu pemilihan bahan, pengupasan, pencucian, pemotongan, pemblenderan dan penyaringan. Pemilihan: buah nanas dipilih yang sudah tua namun tidak terlalu matang. Pengupasan: kulit nanas dikupas dan mata kulitnya dibersihkan. Pencucian: nanas yang sudah dikupas dan dibuang mata kulitnya kemudian dicuci. Pemotongan: nanas dipotong kecil-kecil kemudian dilakukan pemblenderan nanas sampai halus. Penyaringan: dilakukan terhadap air yang dikeluarkan nanas yang sudah diblender. Air dan ampasnya dipisahkan dengan cara disaring. Penyaringan pertama dengan saringan lubang agak besar agar ampas dan sarinya mudah terpisah sedangkan penyaringan kedua dengan kain supaya air nanas bersih dari ampasnya. Air nanas itu disebut dengan ekstrak buah nanas yang mengandung bromelin.

\section{Proses Perendaman dan Pemberian Ekstrak Nanas}

Daging itik afkir direndam cairan ekstrak buah nanas sampai menutupi semua bagian dari daging, hal ini untuk menentukan perubahan kadar $\mathrm{pH}$, susut masak dan keempukan, digunakan daging itik tegal bagian paha sebanyak 8 buah. Daging itik ditusuk - tusuk dengan garpu dan diolesi ekstrak buah nanas masing-masing 0 (tanpa perlakuan), $10 \mathrm{ml}$ ekstrak buah nanas dalam 100 gram daging, dan $20 \mathrm{ml}$ ekstrak buah nanas dalam 100 gram daging diinkubasi selama 15, 30 dan 45 menit pada suhu kamar sesuai perlakuan. 
Tabel 1. Level ekstrak buah nanas (Ananas comosus L, Merr) dan lama perendaman terhadap kualitas daging itik afkir

\begin{tabular}{clcccc}
\hline No & Peubah yang di amati & A & B & AB & KK $(\%)$ \\
\hline 1. & Susut Masak & $2,52^{\text {tn }}$ & $2,37^{\text {tn }}$ & $1,65^{\text {tn }}$ & 18,87 \\
2. & pH & $2,14^{\text {tn }}$ & $0,20^{\text {tn }}$ & $0,48^{\text {tn }}$ & 2,35 \\
3. & Kadar Protein & $0,30^{\text {tn }}$ & $6,08^{*}$ & $3,21^{*}$ & 8,17 \\
4. & Kadar Lemak & $2,23^{\text {tn }}$ & $10,04^{* *}$ & $6,03^{* *}$ & 21,55 \\
5. & Kadar Air & $2,38^{\text {tn }}$ & $1,19^{\text {tn }}$ & $0,47^{\text {tn }}$ & 3,56 \\
\hline
\end{tabular}

Keterangan: A = Konsentrasi Ekstrak Buah Nanas, B = Lama Perendaman dengan Ekstrak Buah Nanas, AB $=$ Interaksi, tn $=$ Berpengaruh tidak nyata, $*=$ Berpengaruh nyata, $* *=$ Berpengaruh sangat nyata, KK= Koefisien Keragaman

\section{Proses Pemasakan}

Proses pemasakan paha itik setelah perendaman selama 30 menit. Kemudian di masukan ke dalam plastik agar terlihat sari dari daging itik tersebut setelah pemasakan. Pemasakan di lakukan selama 30 menit setelah air mendidih. Setelah 30 menit kemudian daging ditiriskan sampai dingin kemudian dilakukan penelitian untuk mengetahui kadar $\mathrm{pH}$, susut masak, dan keempukan daging itik bagian paha tersebut.

\section{Peubah yang Diamati}

Adapun variabel yang diamati dalam penelitian ini adalah kadar air daging, uji $\mathrm{pH}$, uji susut masak, kadar lemak daging, dan kadar protein daging.

\section{HASIL DAN PEMBAHASAN}

Hasil analisis keragaman menunjukkan bahwa perlakuan lama perendaman menggunakan ekstrak buah nanas (Ananas comosus L. Merr) memberikan pengaruh sangat nyata $(\mathrm{P}<0,01)$ terhadap kadar lemak daging itik afkir, berpengaruh nyata terhadap kandungan protein daging itik afkir dan berpengaruh tidak nyata $(\mathrm{P}>0,05)$ terhadap susut masak, $\mathrm{pH}$, dan kadar air (Tabel 1).

Salah satu faktor yang mempengaruhi tingkat keempukan daging adalah pengaruh dari umur ternak (itik afkir) serta tingginya protein jaringan pengikat yang berbanding lurus dengan bertambahnya umur ternak sehingga meningkatkan kealotan daging, Lawrie (2003) menyatakan bahwa dalam mengempukkan daging dan meningatkan daya konsumsi daging itik afkir perlu adanya pengolahan daging yaitu dengan cara perendaman daging menggunakan ekstrak buah nanas (Ananas comosus L. Merr), daging nanas mengandung enzim protease yang disebut enzim bromeline. Salah satu faktor penting dalam menentukan kualitas daging adalah Tekstur daging itu sendiri. Tekstur otot pada daging dibagi menjadi dua kelas, yaitu tekstur kasar dan tekstur halus (Lawrie, 1995). Menurut Forrest (1975) dalam Maghfiroh et al. (2016), daging dengan penampilan yang halus dan empuk memiliki struktur otot daging yang kecil sebaliknya otot besar akan menghasilkan daging yang berpenampilan kasar dan liat Peningkatan ukuran diameter otot selaras dengan meningkatnya umur ternak itu sendiri.

Menurut Chartrin (2006), kandungan lemak yang tebal pada unggas air berpengaruh terhadap aroma pada daging itik. Menurut Rupsankar (2010), perlemakan sebagian besar menyebar di bawah kulit pada ternak unggas, tebalnya kulit itik antara lain disebabkan oleh penyebaran lemak di bawahnya. Semakin bertambahnya usia akan meningkatkan ketebalan dibawah kulit.

Daging itik termasuk daging gelap karena sebagian besar komposisinya terdiri atas serat-serat merah (Soeparno, 2009). Komariah (2004) menyatakan bahwa warna 
Table 2. Penambahan ekstrak buah nanas dan lama perendaman terhadap susut masak daging itik afkir

\begin{tabular}{lcccc}
\hline \multirow{2}{*}{ Faktor A } & \multicolumn{3}{c}{ Faktor B } & \multirow{2}{*}{ Rerata } \\
\cline { 2 - 4 } & B0 & B1 & B2 & \\
\hline A0 & 26,67 & 25,33 & 36,67 & 29,5 \\
A1 & 25,00 & 32,67 & 27,67 & 28,4 \\
A2 & 30,67 & 36,67 & 35,33 & 34,2 \\
\hline Rerata & 27,4 & 31,5 & 33,2 & \\
\hline
\end{tabular}

Keterangan: Faktor A = level ekstrak buah nanas, Faktor $\mathrm{B}=$ lama perendaman

yang lebih gelap dari warna normal daging memperlihatkan tingginya $\mathrm{pH}$. Derajat keasaman $(\mathrm{pH})$ daging di atas titik isoelektrik $(\mathrm{pH}>5,2-5,4)$ berakibat protein menjadi lebih bermuatan negatif. Tingginya muatan negatif akan meningkatkan kekuatan tolak-menolak antara protein di dalam miofilamen yang pada akhirnya akan memudahkan myofibril untuk mengembang dan menahan air.

\section{Level ekstrak buah nanas dan lama perendaman terhadap Susut Masak (\%)}

Berat yang hilang akibat pemanasan, perebusan dan pemasakan adalah susut masak. Nilai nutrisi daging dipengaruhi oleh susut masak yaitu banyaknya air yang terikat didalam dan diantara serabut otot daging. Semakin besar susut masak maka nilai nutrisi daging akan semakin rendah sebaliknya nilai susut masak yang rendah nilai nutrisi semakin baik karena kehilangan nilai nutrisi lebih sedikit (Soeparno, 2009).

Pada penelitian ini nilai susut masak memberikan pengaruh yang tidak nyata $(\mathrm{P}>0,05)$ pada konsentarasi, lama perendaman dan interaksi keduanya. Hasil pengamatan tertinggi pada perlakuan A2 dengan konsentrasi $20 \%$ yaitu $34,2 \%$ dan terendah pada A1 dengan konsentrasi $10 \%$ yaitu 28,4\% (Tabel 2). Hal ini diduga karena semakin banyak konsentrasi ekstrak buah nanas yang ditambahkan lebih banyak lemak yang larut, sehingga akan menurunkan nilai susut masak daging. Pada lama perendaman tertinggi pada perlakuan B2 yaitu dengan lama perendaman 45 menit dan terendah pada perlakuan B0 dengan lama perendaman 15 menit, sedangkan interaksi perlakuan terbaik untuk susut masak terdapat pada perlakuan A1B2 dan A2B0 yaitu dengan konsentrasi $10 \%$ dan $20 \%$ dan lama perendaman 15 dan 45 menit.

Pengaruh yang tidak nyata pada perlakuan hal ini dikarenakan enzim proteolitik pada ekstrak nanas belum mampu bekerja sehingga memberikan pengaruh yang tidak nyata terhadap semua peubah yang diamati. Enzim protease yang tidak mampu masuk kedalam daging dan menambah jumlah protein terlarut akan menyebabkan tidak terjadinya perubahan yang nyata $(\mathrm{P}>0,05)$ terhadap susut masak. Hal ini sesuai dengan pendapat Shanks et al. (2002), besarnya susut masak dipengaruhi oleh banyaknya kerusakan membran seluler, banyaknya air yang keluar dari daging, degradasi protein dan kemampuan daging untuk mengikat air dan menurut Obuz et al. (2004), meningkatnya susut masak ada hubungannya dengan serat otot dan penyusutan kolagen. Pengaruh yang tidak nyata pada susut masak juga dipengaruhi oleh laju penurunan $\mathrm{pH}$ daging itik afkir yang diamati. Menurut Lawrie (2003) nilai susut masak daging yang normal adalah $1,5 \%$ sampai $54,5 \%$ dengan kisaran $15 \%-40 \%$. Sifat mekanik daging termasuk susut masak merupakan indikasi dari sifat mekanik miofibril dan jaringan ikat dengan bertambahnya umur ternak, terutama peningkatan panjang Sarkomer. Menurut Illanes (2008), penambahan ekstrak buah nanas dapat menurunkan nilai susut masak daging. Ekstrak buah nanas yang mengandung bromelin menghidrolisis jaringan ikat protein 
Tabel 3. Penambahan ekstrak buah nanas dan lama perendaman terhadap $\mathrm{pH}$ daging itik afkir

\begin{tabular}{lcccc}
\hline \multirow{2}{*}{ Faktor A } & \multicolumn{3}{c}{ Faktor B } & \multirow{2}{*}{ Rerata } \\
\cline { 2 - 4 } & B0 & B1 & B2 & \\
\hline A0 & 6,05 & 6,13 & 6,17 & 6,11 \\
A1 & 6,09 & 6,08 & 6,14 & 6,10 \\
A2 & 6,24 & 6,29 & 6,17 & 6,23 \\
\hline Rerata & 6,12 & 6,16 & 6,16 & \\
\hline
\end{tabular}

Keterangan: Faktor $\mathrm{A}=$ level ekstrak buah nanas, Faktor $\mathrm{B}=$ lama perendaman

daging diantaranya kolagen daging, sehingga dapat membuka struktur mikro daging dengan terputusnya miofibril.

Pengujian susut masak menggunakan metode pemasakan yang mengakibatkan terjadinya gap cairan daging dan cairan tersebut dapat tereksudasi keluar mikro struktur daging (Soeparno, 2005), sehingga terjadi penurunan nilai susut masak pada daging. Susut masak mengalami penurunan dengan bertambahnya waktu pemasakan. Protein dengan pemanasan terdenaturasi, teragulasi dan mencair membentuk gelatin yang akhirnya termobilisasi bercampur lemak dan air (Judge et al., 1989). Perubahan tersebut dapat menyebabkan cairan daging keluar secara perlahan ketika pemasakan, sehingga daging yang dimasak lebih lama memiliki susut masak lebih kecil.

\section{Level ekstrak buah nanas dan lama perendaman terhadap $\mathrm{pH}$}

$\mathrm{pH}$ daging merupakan tingkat derajat keasaman dari daging. $\mathrm{pH}$ ditentukan karena pembentukan asam laktat pada daging yang merupakan hasil dari terjadinya proses glikogenolisis pada hewan, nilai $\mathrm{pH}$ daging berada pada kisaran 5,4 - 7,0. Kemudian terjadi peningkatan $\mathrm{pH}$ akibat pertumbuhan mikroorganisme (Forrest et al., 1975) dalam Maghfiroh et al. (2016).

Berdasarkan hasil penelitian nilai $\mathrm{pH}$ memberikan pengaruh yang tidak nyata $(\mathrm{P}>0,05)$ terhadap konsentrasi, lama perendaman dan interaksi ekstra buah nanas. Hasil pengamatan menunjukkan bahwa perlakuan A2 memiliki nilai $\mathrm{pH}$ tertinggi yaitu 6,23 dan terendah pada A1 yaitu
6,10. Pada perlakuan lama perendaman (B) tertinggi terdapat pada perlakuan B1 dan B2 yaitu 6,16 dan terendah pada B0 yaitu 6,12. Untuk interaksi perlakuan, hasil terbaik untuk peubah nilai $\mathrm{pH}$ terdapat pada kombinasi perlakuan A2B1 yaitu 6,29 dan terendah pada perlakuan A0B0 yaitu 6,05 (Tabel 3). Hal ini disebabkan dengan adanya gugus hidrogen pada peptide yang merupakan molekul organik polar, sehingga akan membentuk air dengan adanya gugus $\mathrm{OH}$. Penambahan ekstrak buah nanas mengakibatkan protein jaring ikat terhidrolisis menjadi beberapa asam amino penyusunnya, sehingga dihasilkan beberapa residu asam amino yang bersifat hidrofilik yang dapat meningkatkan $\mathrm{pH}$ daging terhadap semua peubah yang diamati. Hal ini sependapat dengan Sunarsih (2008) bahwa terjadi peningkatan $\mathrm{pH}$ daging dengan semakin meningkatnya konsentrasi ekstrak buah nanas.

Enzim bromelin mampu memecah molekul-molekul protein daging menjadi bentuk yang lebih sederhana (asam amino), dengan memutus ikatan protein jaringan ikat. Hal ini disebabkan oleh adalah Protein yang mengandung asam amino bersifat hidrofilik, yaitu protein yang residu asam aminonya bersifat menyukai air. Hal ini disebabkan dengan adanya gugus hidrogen pada peptida yang merupakan molekul organik polar, sehingga akan membentuk air dengan adanya gugus $\mathrm{OH}$ (Florence and Attwood, 2011).

Penambahan ekstrak buah nanas akan berakibat terhidrolisis protein jaringan ikat pada daging itik menjadi beberapa asam amino, dihasilkan beberapa residu asam 
Tabel 4. Penambahan ekstrak buah nanas dan lama perendaman serta interaksinya terhadap kadar protein daging itik afkir

\begin{tabular}{ccccc}
\hline \multirow{2}{*}{ Faktor A } & \multicolumn{3}{c}{ Faktor B } & \multirow{2}{*}{ Rerata } \\
\cline { 2 - 4 } & B0 & B1 & B2 & \\
\hline A0 & $22,91^{\mathrm{bA}}$ & $21,70^{\mathrm{aA}}$ & $22,39^{\mathrm{bA}}$ & 22,33 \\
A1 & $20,70^{\mathrm{aA}}$ & $24,63^{\mathrm{bB}}$ & $21,12^{\mathrm{aA}}$ & 22,15 \\
A2 & $21,32^{\mathrm{aA}}$ & $24,78^{\mathrm{bB}}$ & $18,99^{\mathrm{aA}}$ & 21,69 \\
\hline Rerata & $21,64^{\mathrm{a}}$ & $23,70^{\mathrm{a}}$ & $20,83^{\mathrm{a}}$ & \\
\hline
\end{tabular}

Keterangan: Superskrip yang berbeda pada kolom atau baris yang sama menunjukkan perbedaan yang sangat nyata $(\mathrm{P}<0,01)$. Faktor $\mathrm{A}=$ level ekstrak buah nanas, Faktor $\mathrm{B}=$ lama perendaman

amino yang bersifat hidrofilik, sehingga dapat meningkatkan $\mathrm{pH}$ daging akibat ikatan air oleh residu asam amino tersebut. Bertambahnya waktu pemasakan dapat meningkatkan $\mathrm{pH}$ daging. Perubahan-perubahan denaturasi protein dalam sarkoplasma dapat mempengaruhi peningkatan $\mathrm{pH}$ daging (Lawie, 2005), selanjutnya menurun Sudrajat (2003) denaturasi protein diakibatkan oleh lamanya pemasakan sehingga protein kehilangan gugus dan $\mathrm{pH}$ meningkat. Penambahan ekstrak buah nanas dan waktu pemasakan menyebabkan hidrolisis dan denaturasi protein, sehingga pada konsentrasi ekstrak buah nanas semakin meningkat memerlukan waktu pemasakan yang lebih pendek. Hal ini berhubungan dengan jumlah residu asam amino yang terbentuk dan hilangnya gugus protein.

Menurut Buckle et al. (1987) dalam Maghfiroh et al. (2016) pH tinggi 6,2 - 7,2 menyebabkan daging mempunyai struktur tertutup dan padat. Struktur tertutup pada daging menyebabkan penetrasi air ke dalam daging tidak sempurna, sehingga merubah keseimbangan hidrogen. Sehingga hasil penelitian ini secara statistik menujukkan bahwa penambahan konsentrasi ekstrak kulit nanas dengan konsentrasi 15\%, 30\% dan 45\% belum bisa memperbaiki nilai $\mathrm{pH}$.

\section{Level ekstrak buah nanas dan lama perendaman terhadap Kadar Protein (\%)}

Hasil Penelitian didapatkan bahwa konsentrasi ekstrak buah nanas memberikan pengaruh yang tidak nyata $(\mathrm{P}>0,05)$ dan berpengaruh nyata $(\mathrm{P}<0,05)$ terhadap lama perendaman dan interaksi ekstrak buah nanas terhadap kadar protein. Hasil pengamatan kadar protein tertinggi terdapat pada interaksi perlakuan A2B1 sebesar 24,78\% sedangkan kadar protein terendah pada perlakuan A2B2 sebesar 18,99\% (Tabel 4). Hal ini diduga oleh fungsi enzim bromelin sebagai enzim protease yang mengubah struktur kuartener protein menjadi lebih sederhana. Menurut Ketnawa dan Rawdkuen (2011) bahwa enzim sendiri merupakan protein tapi tidak ikut menjadi hasil reaksi, hanya mempercepat atau memperlambat reaksi reaksi saja, oleh sebab itu jika lingkungan (suhu dan $\mathrm{pH}$ ) yang digunakan optimal maka enzim akan bekerja maksimal. Kadar protein turun karena terjadi degradasi struktur protein atau proteolisis kolagen jadi hidroksi prolin sehingga menghasilkan fragmen protein dengan rantai peptida lebih pendek. Semakin banyak proteolisis maka protein terlarutnya semakin banyak sehingga kadar protein turun.

Lama perendaman pada ekstrak nanas menunjukkan berbeda nyata $(\mathrm{P}<0,05)$ terhadap kadar protein daging itik afkir. Penurunan kadar protein ini disebabkan lama perendaman daging paha itik afkir akan menurun. Hal ini sesuai dengan pendapat Naiola dan Widyastuti (2002) bahwa protease adalah enzim yang mengkatalisasi pemecahan ikatan peptida dalam peptida, polipeptida dan protein dengan menggunakan reaksi hidrolisis menjadi molekul yang lebih sederhana seperti peptida rantai pendek dan asam amino

Menurut Radiati (2010), aktivitas 
Tabel 5. Penambahan ekstrak buah nanas dan lama perendaman terhadap kadar lemak daging itik afkir

\begin{tabular}{ccccc}
\hline \multirow{2}{*}{ Faktor A } & \multicolumn{3}{c}{ Faktor B } & \multirow{2}{*}{ Rerata } \\
\cline { 2 - 3 } & $\mathrm{B} 0$ & $\mathrm{~B} 1$ & $\mathrm{~B} 2$ & \\
\hline $\mathrm{A} 0$ & $7,50^{\mathrm{bA}}$ & $8,43^{\mathrm{bB}}$ & $12,17^{\mathrm{cB}}$ & 9,36 \\
$\mathrm{~A} 1$ & $8,36^{\mathrm{bB}}$ & $3,44^{\mathrm{aA}}$ & $10,84^{\mathrm{cB}}$ & 7,55 \\
A2 & $11,02^{\mathrm{cB}}$ & $7,27^{\mathrm{bA}}$ & $7,49^{\mathrm{bA}}$ & 8,59 \\
\hline Rerata & $8,96^{\mathrm{a}}$ & $6,38^{\mathrm{a}}$ & $10,17^{\mathrm{b}}$ & \\
\hline
\end{tabular}

Keterangan: Superskrip yang berbeda pada kolom atau baris yang sama menunjukkanperbedaan yang sangat nyata $(\mathrm{P}<0,01)$. Faktor $\mathrm{A}=$ level ekstrak buah nanas, Faktor $\mathrm{B}=$ lama perendaman

enzim bromelin optimum pada $\mathrm{pH}$ 6,5 dimana enzim bersifat konstan dan juga mempunyai aktivitas yang maksimum dan suhu optimum untuk enzim bromelin adalah $50^{\circ} \mathrm{C}$, di atas atau di bawah suhu tersebut keaktifan enzim menjadi lebih rendah. Apabila suhu berada dibawah suhu optimal maka substrat dan enzim untuk beraksi menjadi lebih kecil dan kecepatan reaksi lebih rendah

Sebab lain adanya pengaruh nyata kadar protein terhadap lama perendaman hal ini diduga oleh adanya pengaruh panas dan $\mathrm{pH}$. Sejalan dengan pendapat Soeharsono (1989) dalam Soeparno (2005), yang menyatakan berdasarkan struktur molekulnya, pada dasarnya asam amino merupakan senyawa yang bermuatan ganda (zwitter ion), keadaan ini mudah berubah karena dipengaruhi oleh keadaan sekitar atau $\mathrm{pH}$ lingkungan.

Pada penelitian ini daging itik afkir dilakukan pemasakan sehingga menstimulir terjadinya denaturasi protein. Menurut Winarno (1992), denaturasi protein adalah pengembangan rantai pendek akibat membukaan gugus reaktif pada rantai polipeptida. Bila unit ikatan yang terbentuk cukup banyak sehingga protein tidak lagi terdispersi sebagai suatu koloid, maka protein tersebut mengalami koagulasi. Apabila ikatan-ikatan antara gugus-gugus reaktif protein tersebut menahan seluruh cairan, akan terbentuk gel, sedangkan bila cairan terpisah dari protein yang terkoagulasi itu, protein akan mengendap. Oleh karenanya semakin meningkat konsentrasi ekstrak buah nanas, semakin meningkatkan kadar protein.

\section{Level ekstrak buah nanas dan lama perendaman terhadap Kadar Lemak (\%)}

Dari hasil penelitian didapatkan bahwa konsentrasi ekstrak buah nanas memberikan pengaruh yang tidak nyata $(\mathrm{P}>0,05)$ dan berpengaruh sangat nyata $(\mathrm{P}<0,01)$ terhadap lama perendaman dan interaksi ekstrak buah nanas terhadap kadar Lemak. Hasil pengamatan menunjukan bahwa kadar lemak tertinggi terdapat pada konsentrasi ekstrak nanas $0 \%$ sebesar $9,36 \%$ dan lama perendaman 45 menit yaitu sebesar $10,17 \%$, sedangkan kadar lemak terendah terdapat pada konsentrasi ekstrak nanas 10\% sebesar 7,55\% dan lama perendaman 30 menit yaitu sebesar 6,38\% (Tabel 5). Hal ini sependapat dengan Fenita et al. (2009) bahwa ekstrak nanas dapat menurunkan kadar lemak daging itik afkir. Variasi komposisi kimia antara kadar lemak dan protein pada daging itik memberikan refleksi satu dengan lain, berbanding lurus jika kadar lemak tinggi maka kadar protein rendah.

Pemberian ekstrak nanas dapat menurunkan kadar lemak daging itik afkir. Peningkatan kadar lemak dapat disebabkan karena emulsi lemak dan adanya komposisi asam lemak baru dan asam lemak bebas dari hasil kerja enzim-enzim yang terdapat didalambuah nanas tersebut. Hal ini sesuai dengan pendapat Sibuea (2002) dalam Fenita et al. (2009), bahwa ekstrak buah nanas mengandung serotonin yang berfungsi menurunkan kadar kolesterol dalam darah 
Tabel 6. Data tabulasi perlakuan penambahan ekstrak buah nanas dan lama perendaman serta interaksinya terhadap kadar air daging itik afkir

\begin{tabular}{ccccc}
\hline \multirow{2}{*}{ Faktor A } & \multicolumn{3}{c}{ Faktor B } & \multirow{2}{*}{ Rerata } \\
\cline { 2 - 4 } & B0 & B1 & B2 & 63,61 \\
A0 & 64,41 & 64,11 & 61,66 & 65,57 \\
A1 & 65,83 & 65,91 & 64,99 & 63,72 \\
A2 & 64,91 & 62,77 & 63,51 & \\
\hline Rerata & 65,27 & 64,26 & 63,38 & \\
\hline
\end{tabular}

Keterangan: Faktor $\mathrm{A}=$ level ekstrak buah nanas, Faktor $\mathrm{B}=$ lama perendaman

yang akhirnya akan menurunkan kadar lemak. Selanjutnya dinyatakan oleh Muramatsu (1986) dalam Fenita et al. (2009), bahwa zatzat aktif seperti Saponin, vitamin C, flavonoid, dan tanin juga mampu menurunkan akumulasi lemak. Percobaan ini, nanas hanya sebagai perendam tidak mempengaruhi metabolisme pembentukan lemak dan perendaman tidak menunjukkan adanya hidrolisis terhadap lemak, sehingga komposisi lemak relatif konstan.

\section{Level ekstrak buah nanas dan lama perendaman terhadap Kadar Air (\%)}

Berdasarkan hasil penelitian kadar air memberikan pengaruh yang tidak nyata $(\mathrm{P}>0,05)$ terhadap konsentrasi, lama perendaman dan interaksi ekstra buah nanas. Perlakuan A1 memiliki nilai kadar air daging itik afkir relatif tinggi yaitu $65,57 \%$ dan relatif rendah pada $A 0$ yaitu $63,61 \%$. Pada perlakuan lama perendaman (B) tertinggi terdapat pada perlakuan B0 yaitu $65,27 \%$ dan terendah pada B2 yaitu $63,38 \%$, dan untuk interaksi perlakuan, hasil terbaik untuk peubah nilai kadar air daging itik afkir terdapat pada kombinasi perlakuan A1B1 yaitu 65,91\% dan terendah pada perlakuan A0B2 yaitu 61,66\% (Tabel 6).

Hal ini dikarenakan kemampuan daging itik afkir untuk menyerap air dari lingkungan pada kondisi yang jenuh. Namun demikian secara statistik tidak ada perbedaan, dikarenakan kondisi daging itik afkir sudah tidak mampu untuk melakukan penyerapan air. Tidak ada perubahan ion $\mathrm{H}+$ akibat pemberian kombinasi ekstrak buah nanas, sehingga kadar air pada perlakuan tidak memberikan adanya perbedaan, serta diduga pada kondisi tersebut kemampuan daging untuk menyerap air dari lingkungan pada kondisi yang jenuh. Faktor umur berpengaruh pada nilai kadar air daging ternak tersebut. Tilman (1989), berpendapat bahwa kadar air menurun dengan bertambahnya umur ternak, sebaiknya kadar lemak cenderung naik sampai stadium kedewasaan tercapai. Kadar air daging mencapai $75 \%$ dalam tubuh ternak. Penambahan ekstrak buah nanas $20 \%$ dengan waktu perendaman 15 menit merupakan interaksi yang paling tinggi. Hal ini dapat menyebabkan kerusakan, karena kadar air daging yang tinggi merupakan suatu faktor yang mendukung perkembangan jamur dan mikroorganisme, sehingga daging yang berkualitas tinggi kadar airnya harus dalam batas yang normal (Anam et al., 2003).

\section{KESIMPULAN}

Dari hasil penelitian dapat diambil kesimpulan yaitu pada perlakuan A1 $(10 \mathrm{ml})$ level ekstak nanas memberikan pengaruh yang tertinggi sebesar 7,55\% dan lama perendaman B1 (30 menit) merupakan perlakuan terbaik karena mampu menurunkan kadar lemak dan meningkatkan kadar protein daging itik afkir, tetapi tidak memberikan pengaruh yang nyata pada susut masak, pH dan Kadar air daging itik afkir. 


\section{DAFTAR PUSTAKA}

Anam, C., N. S. Rahayu, dan M. Baedowi. 2003. Aktivitas Enzim Bromelin terhadap Mutu Fisik Daging. Jurnal Seminar Nasional dan Pertemuaan Tahunan Perhimpu-nan Ahli Teknologi Pangan Indonesia (PATPI): Peranan Industri dalam Pengembangan Produk Pangan Indonesia. Yogyakarta.

Chang, H. S., N. L. Castro, and M. L. L. Malabayabas. 2013. Duck Marketing in The Philippines: Issues and Opportunities. In: Agricultural and Resource Economic 2005. Page: 1-24.

Chartrin. 2006. Penggunaan Pakan Fungsional Terhadap Daya Ikat Air, Susut Masak, dan Keempukan Daging Ayam Broiler. Jurnal Ilmiah Peternakan Vol. 1, No. 1, Hlm. 10-11. 41: 534.

Dhiah, P. U., Pudjomartatmo, dan Adi Magna, P. N. 2011. Manfaat Bromelin dari Ekstrak Buah Nanas (Ananas comosus L. Merr) dan Waktu Pemasakan untuk Meningkatkan Kualitas Daging Itik Afkir. Sains Peternakan Vol. 9, No.2 : 82-87 ISSN 1693-8828.

Fenita, Y., O. Mega, dan E. Daniati. 2009. Pengaruh Pemberian Air Nanas (Ananas cosumus) terhadap Kualitas Daging Ayam Petelur Afkir. Jurnal Sain Peternakan Indonesia Vol. 4, No 1. Jurusan Peternakan Fakultas Pertanian Universitas Bengkulu.

Florence,A. T. and D. Attwood. 2011. Peptides, Proteins and Other Biopharmaceuticals. In: Physicochemical Principles of Pharmacy. Pharmaceutical Press Pub., London, United Kingdom. Page:451476.

Illanes. 2008. Enzyme Production. In: Enzyme Biocatalysis: Principles and Applications: Enzyme Production. A. Illanes, Ed. Springer Pub., Chile. Page: 57- 106.

Judge, M. D., E. D. Aberle., J. C. Forrest., H. B. Hedrick, and R. A. Merkel. 1989.
Principles of Meat Scince. 2nd ed. Kendal/Hunt Pub. Co., Dubuque, Iowa.

Ketnawa, S and S. Rawdkuen. 2011. "Application of Bromelain Extract for Muscle Foods Tenderization," Food and Nutrition Sciences, Vol. 2 No. 5, 2011, pp. 393-401.

Komariah, I. 2004. Kualitas fisik dan mikroba daging sapi yang ditambah jahe (Zingiber officinale roscoe) pada konsentrasi dan lama penyimpanan yang berbeda. Media Peternakan Hal. 46-54.

Latifa, R. 2007. Pengembangan Teknik Pemanfaatan Cairan Folikel Ovarium Kambing Sebagai Upaya untuk Meningkatkan Produktivitas Itik Petelur Afkir. J. Protein. 15 (2): 225249.

Lawrie, R. A. 2003. Meat science. Edisi Ke5. Penerjemah: A. Perakasi. UI press. Jakarta.

Maghfiroh, M., Dewi, R. K. dan Susanto E. 2016. Pengaruh Konsentrasi dan Lama Perendaman Ekstrak Kulit Nanas Terhadap Kualitas Fidik dan Kualitas Organoleptik Daging Bebek Petelur Afkir. Media Peternakan Hal.1-11.

Naiola, E. dan Widhyastuti, N. 2002. Isolasi, Seleksi dan Optimasi Produksi Protease dari beberapa Isolat Bakteri. Hayati 6:467-473.

Obuz, E., M. E. Dikeman., J. P. Grobbel., W. Stephens, and T. M. Loughin. 2004. Beef Longissimus Lumborum, Biceps Femoris And Deep Pectoralis WarnerBratzler Shear Force Is Affected Differently By Endpoint Temperature, Cooking Method And Usda Quality Grade. Meat Sci. 68:243-248.

Oteku, I. T., Igene, J. O. and Yessuf, I. M. 2006. Anassessment of the factors influencing theconsumption of duck meat in Southern Nigeria. Pakistan J. Nutrition 5 (5) : 474-477.

Radiati, L. E. 2010. Renin Mikroba.Lab. 
Ilmu Faal. FK. Universitas Brawijaya. Malang.

Rupsankar. 2010. Beternak Itik Petelur. Penerbit Agro Media Pustaka. Semarang.

Savitri, R. D. 2011. Aplikasi Proses Hidrolisis Enzimatis dan Fermentasi dalam Pengolahan Condiment Kupang Putih (Corbula faba H). Departemen Teknologi Hasil Perairan Fakultas Perikanan dan Ilmu Kelautan Institut Pertanian Bogor. Bogor.

Shanks, B.C., D. M. Wolf, dan R. J. Maddock. 2002. Technical note: The effect of freezing on Warner Bratzler shear force values of beef longissimus steak across several postmortem aging periods. J. Anim. Sci. 80:2122-2125.

Soeparno. 2009. Ilmu dan Teknologi Daging. Gadjah Mada University Press. Yogyakarta.

Srigandono, B. 2011. Ilmu Unggas Air. UGM Press. Yogyakarta.
Sudrajat, A. 2003. Pengaruh Temperatur dan Lama Pemasakan terhadap Karakteristik Fisik dan Organoleptik Daging Ayam Broiler. Gadjah Mada University Press. Yogyakarta.

Sunarsih, L. 2008. Uji Efektivitas Ekstrak Buah Nanas (Ananas comosus L. Merr) Muda Varietas Queen Terhadap Mortalitas Cacing Parasit (Ascaridia galli) Secara In Vitro. Fakultas Keguruan dan Ilmu Pendidikan. Universitas Muhamadiyah Malang. Malang.

Tillman, A. D., H. Hartadi., S. Reksodiproj., S. Prwawirokusomo, dan L. Lebdosoekojo. 1989. Ilmu Makanan Ternak Dasar. Gajah Mada University Press, Yogyakarta.

Winarno, F. G. 1992. Kimia Pangan dan Gizi. PT. Gramedia Pustaka Utama. Jakarta.

Winarno, F. G. 2009. Enzim Pangan. P.T. Gramedia Pustaka Utama. Jakarta. 